\title{
DIMENSI MUTU PRODUK BALAI LATIHAN PENDIDIKAN TEKNIK (BLPT) KAATEN TOMOHON
}

\author{
Meyriska Christi Howan \\ Paulus A. Pangemanan \\ Leonardus R. Rengkung
}

\begin{abstract}
ABSRACT
The research showed that the process of measuring the dimensions of product quality in Technical Education and Training Center (BLPT) Kaaten reached the total 2569 data retrieval scores indicating the index number of consumer satisfaction measurements of 85,63\% and quite satisfied. This indicates that consumers who buy products at BLPT Kaaten Tomohon are aware of the benefits of BLPT products in terms of product quality dimensions that can be seen from the 8 dimensions of quality, namely performance, features, reliability, suitability, durability, ease of improvement, beauty and perception of quality. The measurement of quality dimension product of BLPT Kaaten Tomohon can be a reference for BLPT Kaaten Tomohon to continuously improve product quality in order to remain competitive in the market.
\end{abstract}

Keywords: dimension, product quality, Technical Education and Training Center (BLPT), Kaaten Tomohon

\begin{abstract}
ABSTRAK
Hasil penelitian menunjukkan proses pengukuran dimensi mutu produk di BLPT Kaaten mencapai total skor pengambilan data 2569 yang menunjukkan angka indeks pengukuran kepuasan konsumen sebesar 85,63\% dan tergolong sangat puas. Hal ini menunjukkan bahwa konsumen yang membelli produk- produk di BLPT Kaaten Tomohon sadar mengenai keunggulan dari produk di BLPT yang dilihat dari segi dimensi mutu (kualitas) produk yang dapat dilihat dari 8 dimensi mutu (kualitas) yaitu kinerja, keistimewaan, keandalan, kesesuaian, daya tahan, kemudahan perbaikan, keindahan dan persepsi terhadap kualitas. Kiranya pengukuran dimensi mutu (kualitas) produk BLPT Kaaten Tomohon dapat menjadi acuan bagi BLPT Kaaten Tomohon untuk terus meningkatkan kualitas produk agar tetap bersaing di pasaran.
\end{abstract}

Kata kunci: dimensi, mutu produk, Balai Latihan Pendidikan Teknik (BLPT), Kaaten Tomohon 


\section{PENDAHULUAN}

\section{Latar Belakang}

Sebuah produk bisa dikatakan produk yang baik bila mampu menjalankan fungsi utamanya dan sesuai dengan harapan atau keinginan konsumen. Produk yang berkualitas merupakan kemampuan suatu barang untuk memberikan hasil / kinerja yang sesuai atau melebihi dari apa yang diinginkan konsumen (Kotler, 2003). Tuntutan konsumen atas peningkatan kualitas (mutu) dari suatu produk dewasa ini semakin bertambah (Dale, 2003). Kualitas memiliki hubungan yang erat dengan kepuasaan dan loyalitas pelanggan. Pelanggan yang memiliki kepuasaan yang tinggi terhadap suatu produk akan memberikan loyalitas yang tinggi pula bahkan akan cenderung memberikan rekomendasi pembelian terhadap produk tersebut. Hal ini sangat memberikan dampak yang cukup baik dalam membantu perusahaan untuk meningkatkan profit perusahaan. Kotler (2005) merumuskan bahwa kualitas merupakan suatu kondisi dinamis yang berhubungan dengan produk, jasa, manusia, proses, dan lingkungan yang memiiki atau melebihi harapan. Harapan tersebut adalah standar kualitas yang dirasakan oleh konsumen terhadap kualitas suatu produk. Kualitas (mutu) merupakan elemen utama bagi peningkatan daya saing suatu produk. Untuk menghasilkan produk yang berkualitas, maka perusahaan harus meningkatkan kinerja manajemen perusahaan yang akan bersinergi terhadap kualitas produk yang diharapkan pelanggan (Whisnu, 2013). Menurut Suwendra (2014) satu hal yang sangat berarti dalam meningkatkan kinerja menghadapi tantangan persaingan dalam era industrialisasi yang semakin kompetitif sekarang ini adalah melalui perbaikan berkelanjutan pada aktivitas bisnis yang terfokus pada konsumen. Pencapaian kualitas pada suatu produk dapat tercermin dari manajemen mutu dimana merupakan semua aktivitas dari fungsi manajemen secara keseluruhan yang menentukan kebijakan kualitas, tujuan-tujuan, dan tanggung jawab serta mengimplementasikan melalui perencanaan kualitas, jaminan kualitas dan peningkatan kualitas produk.

BLPT Kaaten Tomohon adalah salah satu pabrik pengolahan dan pemanfaatan batang kelapa menjadi berbagai jenis dan model furniture yang terletak di Matani 1 Jln. Raya Tomohon - Tondano Minahasa. BLPT Kaaten ini berada dibawah yayasan Sinode GMIM yang sudah berdiri sejak tahun 1992 memiliki banyak peminat baik lokal maupun mancanegara. Perabot dari pohon kelapa banyak diminati dikarenakan serat yang ada dalam pohon kelapa sangat unik dan sangat berbeda dengan kayu - kayu jenis lain. Selain itu Pohon Kelapa sangat mudah ditemukan di Sulawesi Utara khususnya di daerah Minahasa. Banyak pabrik yang menghasilkan berbagai jenis dan model furniture seperti yang dihasilkan oleh BLPT Kaaten, untuk itu demi menjaga eksistensi BLPT Kaaten dituntut untuk terus meningkatkan kualitas sehingga dapat menghasilkan produk yang berkualitas tinggi dan dapat memenuhi kebutuhan pelanggan. Dalam hal ini kualitas produk menjadi hal yang harus diperhatikan oleh perusahaan karena dapat mempengaruhi kepuasan dari pelanggan. Pelanggan merupakan salah satu orientasi dari perusahaan dalam menangani persaingan di pasar (Donny, 2009). Walaupun tingkat kepuasan konsumen dipengaruhi oleh banyak faktor, namun mutu suatu barang sangat berpengaruh terhadap pemenuhan kepuasan. Dengan adanya perubahan teknologi maju secara drastis maka perusahaan diharuskan untuk mengubah cara pandang sekaligus filosofi tentang kualitas seperti mempunyai struktur organisasi yang baik, pelatihan \& desain kerja yang mantap, desain proses yang baik, proses produksi yang andal, dan manajemen pembelian bahan yang prima (Suyadi, 2002). Pengelolaan yang efektif terhadap semua aktifitas manajemen yang ada dalam perusahaan dapat menjamin mutu dan keamanan dari setiap produk yang akan dihasilkan yang tercermin dari manajemen mutu yang dijalankan oleh organisasi bisnis. Tantangan paling besar dihadapi oleh setiap perusahaan adalah masalah pengembangan produk. Pengembangan produk dapat dilakukan oleh personalia dalam perusahaan dengan cara mengembangkan produk yang sudah ada. Perusahaan yang tidak mengadakan atau tidak mampu menciptakan produk baru akan menghadapi resiko seperti penurunan volume penjualan, karena munculnya pesaing yang lebih kreatif, adanya perubahan selera konsumen, munculnya teknologi baru dalam proses produksi (Cannon, dkk, 2008). Gagasan mengenai produk 
sebagai keunggulan atau kepuasan yang potensial bagi konsumen sangatlah penting. Banyak manajer bisnis yang terlalu fokus pada detail teknis dalam memproduksi suatu produk. Disisi lain, banyak konsumen yang memikirkan tentang produk dalam hal total manfaat yang ditawarkannya. Kepuasan tersebut mungkin berupa penawaran produk total yang merupakan perpaduan antara layanan yang baik, fisik yang menarik dengan fitur yang sesuai, panduan yang bermanfaat, pengemasan yang rapi, garansi yang dapat dipercaya, dan bahkan merek yang mudah untuk diingat (Cannon, dkk, 2008).

Kualitas produk juga harus dapat ditentukan oleh cara konsumen memandang produk tersebut. Dari sudut pandang pemasaran, kualitas adalah kemampuan produk untuk memuaskan kebutuhan atau keinginan konsumen. Definisi ini berfokus pada konsumen dan bagaimana konsumen berpikir suatu produk akan memenuhi tujuan tertentu (Cannon, dkk, 2008). Penilaian tentang baik dan buruknya suatu produk dapat ditentukan oleh dimensi kualitas suatu produk. Dimensi kualitas suatu produk menurut Raymon Mc Leod (2001) dapat diukur melalui kinerja, keistimewaan, keandalan, kesesuaian, daya tahan, kemudahan perbaikan, keindahan dan persepsi terhadap kualitas yang didasarkan pada citra atau reputasi suatu produk.

\section{Rumusan Masalah}

Berdasarkan latar belakang diatas maka yang menjadi masalah yaitu bagaimana dimensi mutu(kualitas) produk yang terdiri dari kinerja, keistimewaan, keandalan, kesesuaian, daya tahan, kemudahan perbaikan, keindahan dan persepsi terhadap kualitas dari produk - produk yang dihasilkan oleh BLPT Kaaten Tomohon.

\section{Tujuan Penelitian}

Tujuan dari penelitian ini adalah untuk mengetahui tentang dimensi mutu (kualitas) produk yang terdiri dari kinerja, keistimewaan, keandalan, kesesuaian, daya tahan, kemudahan perbaikan, keindahan dan persepsi terhadap kualitas dari produk-produk yang dihasilkan oleh BLPT Kaaten Tomohon.

\section{Manfaat Penelitian}

Manfaat yang dapat diambil dari penelitian ini adalah sebagai berikut:

I. Bagi Penulis, menerapkan ilmu - ilmu yang dipelajari selama perkuliahan dalam hal ini meningkatkan pengetahuan mengenai dimensi mutu (kualitas) produk pada perusahaan.

II. Bagi perusahaan, diharapkan dengan adanya penelitian ini dapat menjadi bahan pertimbangan dalam hal pengembangan kinerja perusahaan yang berhubungan dengan dimensi mutu (kualitas) produk.

III. Bagi pembaca, dapat menjadi sumber informasi dan masukan yang dapat digunakan dalam penelitian selanjutnya.

\section{METODE PENELITIAN}

\section{Waktu dan Tempat Penelitian}

Penelitian ini dilaksanakan di BLPT Kaaten Tomohon, penelitian ini akan dilaksanakan selama 4 bulan dari persiapan sampai penyusunan laporan yaitu pada bulan Januari 2017 sampai bulan April 2017.

\section{Jenis Pengumpulan Data}

Data yang digunakan dalam penelitian ini adalah data primer dan data sekunder. Data primer adalah data yang diperoleh langsung dilapangan. Data sekunder adalah data yang diperoleh dengan mempelajari dokumentasi perusahaan seperti data pelanggan dan profil perusahaan.

\section{Metode Pengumpulan Data}

Populasi merupakan keseluruhan dari objek penelitian yang menjadi sumber data penelitian (Siregar,2013). Populasi dalam penelitian ini adalah konsumen yang membeli produk di BLPT Kaaten Tomohon. Sampel merupakan suatu prosedur pengambilan data dimana hanya sebagian populasi saja yang diambil dan dipergunakan untuk menentukan sifat serta ciri yang dikehendaki dari suatu populasi (Siregar, 2013). Sampel dalam penelitian ini adalah sebagian dari konsumen yang membeli produk di BLPT Kaaten Tomohon. Dalam hal ini populasi menggunakan data konsumen selama 2 tahun terakhir yaitu sebanyak 250 konsumen, maka pengambilan sampel menggunakan metode simple random sampling (sampel acak sederhana), sampel yang diambil sebanyak 30 responden / konsumen.

\section{Konsep Pengukuran Variabel}

Variabel - variabel yang akan diukur dalam peneltian ini adalah : 
I. Karakteristik Responden, mencakup :

a) Jenis kelamin (laki-laki/perempuan).

b) Umur : usia jumlah tahun konsumen dilahirkan sampai saat menjadi konsumen dalam penelitian (tahun).

c) Pekerjaan : profesi konsumen.

d) Tingkat pendidikan: pendidikan terakhir konsumen.

e) Penghasilan : pendapatan konsumen per bulan.

f) Lamanya menggunakan produk.

II. Dimensi mutu produk yaitu :
a) Kinerja (performance)
1. Kerapihan desain produk
2. Kehalusan produk
3. Kekuatan produk
b) Keistimewaan (Features)
1. Desain produk
2. Kelengkapan aksesoris
3. Keseragaman warna
4. Keseragaman ukuran
c) Keandalan (Reability)
1. Kemampuan produk
2. Keamanan produk
d) Kesesuaian
1. Kesesuaian desain
2. Kesesuaian ukuran
3. Kesesuain bahan material
e) Daya tahan (Durability)
1. Daya tahan cat warna
2. Daya tahan material
3. Daya tahan aksesoris
f) Kemudahan perbaikan
g) Keindahan
1. Tampilan produk
2. Tampilan warna
3. Penggunaan material
h) Persepsi terhadap kualitas.

\section{Analisis Data}

Analisis data dalam penelitian ini adalah deskriptif dengan menggunakan daftar tabel dan angka. Untuk mengukur sikap akan disusun 20 pertanyaan dengan total responden 30 orang. Setiap jawaban dihubungkan dengan bentuk pernyataan atau dukungan sikap yang diungkapkan dengan kata-kata berikut (Tangkulung, 2015) :

$\begin{array}{lcc}\text { Sangat puas } & \text { skor } & 5 \\ \text { Puas } & \text { skor } & 4 \\ \text { Ragu- ragu } & \text { skor } & 3 \\ \text { Tidak puas } & \text { skor } & 2\end{array}$

Sangat tidak puas skor 1

Dengan cara perhitungan skor masingmasing pertanyaan: Jumlah skor tiap kriteria= Capaian skor X Jumlah Responden Untuk:

$\mathrm{S} 5=5 \times 30=150$

$\mathrm{S} 4=4 \times 30=120$

$\mathrm{S} 3=3 \times 30=90$

$\mathrm{S} 2=2 \times 30=60$

$\mathrm{S} 1=1 \times 30=30$

Jumlah skor ideal untuk setiap pertanyaan (skor tertinggi) $=150$. Jumlah skor terendah $=30$. Dengan interpretasi nilai :

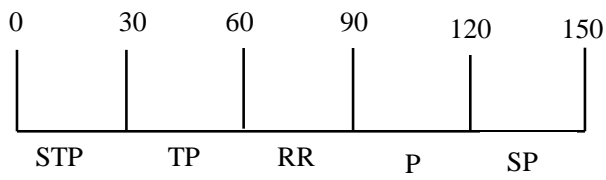

Cara perhitungan skor keseluruhan untuk mengetahui kualitas produk: Jumlah skor seluruh kriteria $=$ Capaian Jumlah Skor X Jumlah Responden $\mathrm{X}$ Instrumen pertanyaan Untuk :

$\mathrm{S} 5=5 \times 30 \times 20=3000$

$\mathrm{S} 4=4 \times 30 \times 20=2400$

$\mathrm{S} 3=3 \times 30 \times 20=1800$

$\mathrm{S} 2=2 \times 30 \times 20=1200$

$\mathrm{S} 1=1 \times 30 \times 20=600$

Jumlah skor ideal untuk keseluruhan pernyataan 3000 (tertinggi). Jumlah skor terendah 600. Dengan interpretasi nilai :

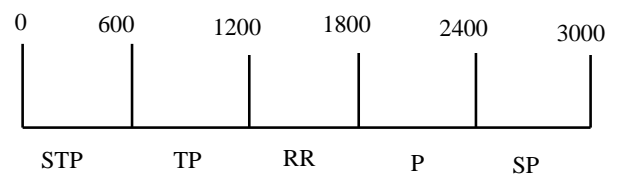

Analisis data yang digunakan merupakan analisis deskriptif yang dianalisis dengan menggunakan skala pengukuran Likert Scale adalah sebagai berikut:

Tingkat kualitas produk $=\underline{\text { Jumlah Skor Hasil Pengumpulan }}$ Data X $100 \%$ Jumlah skor Ideal (tertinggi)

Dengan interpretasi nilai :

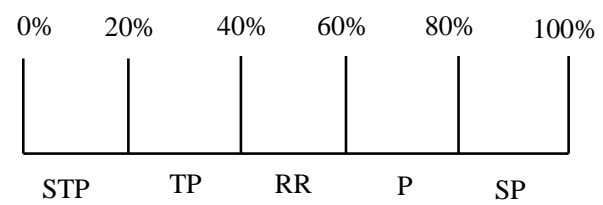

Keterangan Kriteria interpretasi skor kualitas produk: 
Angka $0 \%-20 \%=$ Sangat Tidak Puas

Angka 20\% - 40\% = Tidak Puas

Angka $40 \%-60 \%=$ Ragu-ragu

Angka $60 \%-80 \%=$ Puas

Angka $80 \%-100 \%=$ Sangat Puas

\section{HASIL DAN PEMBAHASAN}

\section{Deskripsi Balai Latihan Pendidikan Teknik (BLPT) Kaaten Tomohon}

Balai latihan pendidikan teknik (BLPT)

Kaaten adalah tempat pelatihan dan pendidikan juga tempat produksi serta pemanfaatan bahan bahan alami yang ada seperti pemanfaatan pohon kelapa yang sudah tidak produktif lagi untuk bahan mebel, bangunan dan souvenir. BLPT Kaaten diresmikan pada tanggal 5 Febuari 1992. BLPT Kaaten sendiri berada dibawah naungan Gereja Masehi Injili di Minahasa. Lokasi BLPT Kaaten berada di Matani 1 Jln. Raya Tomohon -Tondano Minahasa.

\begin{tabular}{llc}
\multicolumn{2}{c}{ Tabel 1. Jumlah karyawan BLPT Kaaten Tomohon } \\
\hline No & \multicolumn{1}{c}{ Jabatan } & Jumlah (orang) \\
\hline 1 & Kepala & 1 \\
2 & Operasional & 1 \\
3 & Bag. Adm. Keuangan & 1 \\
4 & Bag. Produksi & 1 \\
5 & Bag. Marketing/Penjualan & 1 \\
6 & Bag. Personalia & 1 \\
7 & Bag. Persiapan & 7 \\
8 & Bag. Rg. Mesin & 3 \\
9 & Bag. Mebel & 6 \\
10 & Bag. Bangunan & 4 \\
11 & Bag. Finishing & 6 \\
12 & Bag. Pendidikan & 1 \\
13 & Bag. Barang Kecil & 3 \\
14 & Bag. Mekanik & 2 \\
15 & Bag. Gudang & 2 \\
\hline & Total Karyawan & 40
\end{tabular}

Sumber : Data perusahaan BLPT Kaaten Tomohon

BLPT Kaaten sebagai salah satu lembaga pendidikan yang memiliki karyawan dan memproduksi bahan mebel, bangunan serta souvenir. Kegiatan produksi ini bertujuan supaya hasil produksi yang ada akan dapat membantu membiayai program pendidikan di BLPT. Berikut ini merupakan produk- produk yang dihasilkan di BLPT Kaaten Tomohon :

1. Bahan Mebel: Set Meja Makan, Set Kursi
Tamu, Lemari Pakaian, Lemari Pajangan, Tempat Tidur, Kursi Gereja, Tempat Persembahan, dan lain-lain.

2. Sovenir: Salib Pajangan, Papan Nama, Asbak, Catur dan lain-lain.

3. Bahan Bangunan: Rumah panggung.

Jumlah karyawan di BLPT Kaaten dapat dilihat pada Tabel 1 .

\section{Karakteristik Responden}

\section{Jenis Kelamin Responden}

Mengkonsumsi suatu produk pada dasarnya tidak terpengaruh pada jenis kelamin, dalam artian semua konsumen baik laki- laki ataupun perempuan selalu melakukan kegiatan untuk berbelanja produk untuk memenuhi setiap kebutuhannya. Jenis kelamin responden yang berbelanja produk di BLPT Kaaten Tomohon dapat dilihat pada Tabel 2.

\begin{tabular}{|c|c|c|c|}
\hline Tabe & $\begin{array}{l}\text { Jumlah } \\
\text { Kelamin }\end{array}$ & Responden & Menurut \\
\hline No & $\begin{array}{l}\text { Jenis } \\
\text { Kelamin }\end{array}$ & $\begin{array}{l}\begin{array}{l}\text { Jumlah } \\
\text { (orang) }\end{array}\end{array}$ & Presentase $(\%)$ \\
\hline 1 & Laki - laki & 16 & 53,4 \\
\hline 2 & Perempuan & 14 & 46,6 \\
\hline & Jumlah & 30 & 100 \\
\hline
\end{tabular}

Tabel 2 menunjukkan jumlah responden konsumen yang berbelanja produk di BLPT berdasarkan jenis kelamin. Sebagian besar konsumen yang berbelanja adalah yang berjenis kelamin laki-laki dengan jumlah 16 orang $(53,4$ $\%)$ sedangkan konsumen perempuan sebanyak 14 orang $(46,6 \%)$ dari total seluruh responden.

\section{Umur Responden}

Tingkat umur mempengaruhi kemampuan seseorang dalam melakukan aktivitas maupun konsep berpikir, khususnya dalam mengkonsumsi suatu produk. Konsumen yang memiliki umur yang muda tentunya memiliki selera yang berbeda dengan konsumen yang berumur tua. Komposisi umur responden dalam penelitian ini dapat dilihat pada Tabel 3.

Tabel 3 menunjukkan bahwa jumlah responden terbanyak berada pada interval 4150 tahun yaitu sebanyak 14 orang $(46,6 \%)$. Sedangkan jumlah konsumen terendah berada pada interval umur $21-30$ tahun dan $\geq 50$ tahun yaitu 2 orang $(6,7 \%)$. 
Tabel 3. Jumlah Responden Berdasarkan Tingkat Umur

\begin{tabular}{cccc}
\hline No & $\begin{array}{c}\text { Umur Responden } \\
\text { (tahun) }\end{array}$ & $\begin{array}{c}\text { Jumlah } \\
\text { (orang) }\end{array}$ & $\begin{array}{c}\text { Presentase } \\
(\%)\end{array}$ \\
\hline 1 & $\leq 20$ & - & - \\
2 & $21-30$ & 2 & 6,7 \\
3 & $31-40$ & 12 & 40 \\
4 & $41-50$ & 14 & 46,6 \\
5 & $\geq 50$ & 2 & 6,7 \\
\hline & Jumlah & 30 & 100 \\
\hline
\end{tabular}

Sumber : Diolah dari data primer, 2017

\section{Tingkat Pendidikan Responden}

Tingkah laku individu atau seseorang sangat dipengaruhi oleh pendidikan yang telah dicapai. Begitu juga dengan pengambilan keputusan dalam memilih berbagai alternatif pilihan yang hendak dipilih. Seorang konsumen yang memiliki tingkat pendidikan yang tinggi cenderung akan memilih suatu produk berdasarkan kualitas yang lebih baik.

Tabel 4. Jumlah Responden Menurut Tingkat

\begin{tabular}{llcc}
\multicolumn{2}{c}{ Pendidikan } & & \\
\hline No & $\begin{array}{l}\text { Tingkat } \\
\text { Pendidikan }\end{array}$ & $\begin{array}{c}\text { Jumlah } \\
\text { (orang) }\end{array}$ & $\begin{array}{c}\text { Presentase } \\
(\%)\end{array}$ \\
\hline 1 & SD & - & - \\
2 & SMP & 4 & 13,3 \\
3 & SMA & 19 & 63,4 \\
4 & S1 & 6 & 20 \\
5 & S2 & 1 & 3,3 \\
6 & S3 & - & - \\
\hline & Jumlah & 30 & 100 \\
\hline
\end{tabular}

Sumber : Diolah dari data primer, 2017

Tabel 4 menunjukkan bahwa tingkat pendidikan responden yang terbanyak yaitu pada tingkat SMA dimana terdapat 19 orang $(63,4$ $\%)$. Sedangkan tingkat pendidikan responden yang paling sedikit yaitu tingkat pendidikan S2 dimana terdapat 1 orang responden $(3,3 \%)$ dari jumlah responden yang ada.

\section{Pekerjaan Responden}

Jenis pekerjaan juga sangat mempengaruhi cara berpikir seseorang dalam memilih produk mana yang memiliki kualitas baik untuk dikonsumsi. Berikut ini merupakan tabel jumlah responden menurut jenis pekerjaan

Dalam penelitian ini terdapat 4 kategori jenis pekerjaan dari responden, yaitu PNS, Swasta, Wiraswasta, Mahasiswa/ Pelajar. Kategori Wiraswasta merupakan jenis pekerjaan terbanyak dari responden yaitu sebanyak 14 orang $(46,7 \%)$. Sedangkan jenis pekerjaan yang paling sedikit yaitu PNS sebanyak 7 orang $(23,3 \%)$ dari keseluruhan jumlah responden.

\begin{tabular}{|c|c|c|c|}
\hline Tabel & 5. Jumlah F & Responden & Menurut \\
\hline No & Jenis Pekerjaan & $\begin{array}{l}\text { Jumlah } \\
\text { (orang) }\end{array}$ & $\begin{array}{c}\text { Presentase } \\
(\%)\end{array}$ \\
\hline 1 & PNS & 7 & 23,3 \\
\hline 2 & Swasta & 9 & 30 \\
\hline 3 & Wiraswasta & 14 & 46,7 \\
\hline 4 & Mahasiswa/ Pelajar & - & - \\
\hline \multirow[t]{2}{*}{5} & Lainnya & - & - \\
\hline & Jumlah & 30 & 100 \\
\hline
\end{tabular}

Sumber : Diolah dari data primer, 2017

\section{Penghasilan Responden}

Tingkat pendapatan yang dimiliki oleh seseorang sangat mempengaruhi pola berpikir seseorang untuk memenuhi setiap kebutuhannya.

Tabel 6. Jumlah Responden Menurut Penghasilan per Bulan

\begin{tabular}{cccc}
\hline No & $\begin{array}{c}\text { Jumlah Penghasilan } \\
\text { per bulan (juta) }\end{array}$ & $\begin{array}{c}\text { Jumlah } \\
\text { (orang) }\end{array}$ & $\begin{array}{c}\text { Presentase } \\
(\%)\end{array}$ \\
\hline 1 & $2-4$ & 2 & 6,6 \\
2 & $4-6$ & 17 & 56,7 \\
3 & $6-8$ & 8 & 26,7 \\
4 & $8-10$ & 3 & 10 \\
5 & $\geq 10$ & - & - \\
\hline & Jumlah & 30 & 100
\end{tabular}

Sumber : Diolah dari data primer, 2017

Tabel 6 menunjukkan penghasilan responden per bulannya. Konsumen terbanyak memiliki penghasilan pada interval $4-6$ juta yaitu sebanyak 17 orang (56,7 \%). Sedangkan konsumen terendah pada interval $2-4$ juta yaitu sebanyak 2 orang $(6,6 \%)$ dari keseluruhan jumlah responden.

\section{Periode Konsumsi}

Mengkonsumsi suatu produk furniture ada banyak orang yang telah lama mengkonsumsi ada juga yang baru memulai untuk mengkonsumsi karena kesadaran akan kebutuhan dan kemajuan zaman. Tabel 7 menunjukkan lamanya responden mengkonsumsi produk BLPT.

Tabel 7 menunjukkan bahwa lamanya mengkonsumsi responden yang terbanyak yaitu terdapat 18 orang (60\%) sedangkan responden dalam lamanya mengkonsumsi paling sedikit yaitu terdapat 1 orang $(3,3 \%)$ dari jumlah responden yang ada 
Tabel 7. Jumlah Responden Menurut Lamanya

\begin{tabular}{llll}
\multicolumn{5}{c}{ Mengkonsumsi Produk } \\
\hline No & $\begin{array}{l}\text { Lamanya } \\
\text { Konsumsi (tahun) }\end{array}$ & $\begin{array}{l}\text { Jumlah } \\
\text { (orang) }\end{array}$ & $\begin{array}{l}\text { Presentase } \\
(\%)\end{array}$ \\
\hline 1 & 1 & 18 & 60 \\
2 & 2 & 10 & 33,4 \\
3 & 3 & 1 & 3,3 \\
4 & $\geq 3$ & 1 & 3,3 \\
& Jumlah & 30 & 100 \\
\hline
\end{tabular}

Sumber : Diolah dari data primer, 2017

\section{Dimensi Mutu Produk}

Mutu merupakan hal yang sangat penting dalam suatu organisasi apalagi jika berhubungan dengan suatu produk. Mutu suatu produk adalah kecocokkan penggunaan produk untuk memenuhi kebutuhan dan keinginan pelanggan. Semakin besar pelanggan puas dengan suatu produk maka bisa dikatakan produk tersebut bermutu. Mutu bisa diukur dari beberapa dimensi, sehingga dengan dimensi ini bisa dianalisis apakah suatu produk bermutu atau tidak.

\section{Kinerja (Performance)}

Kinerja (performa) merupakan karakteristik utama yang dipertimbangkan pelanggan ketika ingin membeli suatu produk. Pelanggan akan membeli produk karena fungsi yang melekat pada produk tersebut. Kinerja dari suatu produk menekankan pada seberapa baik kegunaan suatu produk sesuai dengan fungsi yang diharapkan. Kinerja suatu produk dapat diukur melalui 3 indikator yaitu : Kerapihan desain produk, kehalusan produk dan kekuatan produk.

\section{Kerapihan desain produk}

Desain produk merupakan salah satu kunci kesuksesan sebuah produk di pasaran. Desain produk yang menarik, akan semakin menambah nilai dari sebuah produk. Ditambah lagi dengan kerapihan dari desain produk tersebut.

Tabel 8. Kerapihan Desain Produk

\begin{tabular}{lcccc}
\hline $\begin{array}{l}\text { Alternatif } \\
\text { Jawaban }\end{array}$ & $\begin{array}{c}\text { Alternatif } \\
\text { Skor }\end{array}$ & $\begin{array}{c}\text { Jumlah } \\
\text { (orang) }\end{array}$ & $\begin{array}{c}\text { Presentase } \\
(\%)\end{array}$ & $\begin{array}{c}\text { Total } \\
\text { Skor }\end{array}$ \\
\hline Sangat & 5 & 8 & 26,6 & 40 \\
Puas & & & & \\
Puas & 4 & 18 & 60 & 72 \\
Ragu-ragu & 3 & 4 & 13,4 & 12 \\
Tidak puas & 2 & - & - & - \\
Sangat & 1 & - & - & - \\
tidak puas & & & & \\
Total & & 30 & 100 & 124 \\
\hline Sumber
\end{tabular}

Sumber : Diolah dari data primer, 2017
Tabel 8 menunjukkan bahwa 18 orang $(60 \%)$ responden berpendapat bahwa puas dengan pernyataan kerapihan desain produk. 8 orang $(26,6 \%)$ sangat puas dengan pernyataan tersebut dan 4 orang $(13,4 \%)$ masih meragukan pernyataan tersebut. Total skor yang diperoleh dari 30 responden pada indikator pernyataan no 1 ini adalah 124, sehingga rata- rata dukungan sikap konsumen terletak pada daerah puas. Angka indeks persepsi konsumen mengenai kerapihan desain produk yaitu : $124 / 150 \times 100=$ $82.6 \%$, sehingga interpretasi nilainya tergolong sangat puas. Ini menunjukkan bahwa sebagian besar konsumen merasa sangat puas terhadap kerapihan desain produk yang dihasilkan BLPT Kaaten, dilihat dari desainnya yang menarik dan sangat rapi.

\section{Kehalusan produk}

Selain didesain dengan rapi kehalusan dari suatu produk juga sangat penting dalam menambah nilai dari sebuah produk. Tanggapan konsumen dari pernyataan tentang kehalusan produk dapat dilihat pada Tabel 9.

Tabel 9 . Kehalusan Produk

\begin{tabular}{lcccc}
\hline $\begin{array}{c}\text { Alternatif } \\
\text { Jawaban }\end{array}$ & $\begin{array}{c}\text { Alternatif } \\
\text { Skor }\end{array}$ & $\begin{array}{c}\text { Jumlah } \\
\text { (orang) }\end{array}$ & $\begin{array}{c}\text { Presentase } \\
(\%)\end{array}$ & $\begin{array}{c}\text { Total } \\
\text { Skor }\end{array}$ \\
\hline Sangat & 5 & 10 & 33,3 & 50 \\
Puas & & & & \\
Puas & 4 & 16 & 53,4 & 64 \\
Ragu- ragu & 3 & 4 & 13,3 & 12 \\
Tidak puas & 2 & - & - & - \\
Sangat & 1 & - & - & - \\
tidak puas & & & & \\
Total & & 30 & 100 & 126 \\
\hline
\end{tabular}

Sumber : Diolah dari data primer, 2017

Tabel 9 menunjukkan bahwa 16 orang $(53,4 \%)$ responden puas dengan kehalusan produk yang dihasilkan oleh BLPT Kaaten. 10 orang $(33,3 \%)$ sangat puas dan 4 orang $(13,3 \%)$ masih ragu - ragu. Total skor yang diperoleh dari 30 responden pada indikator kehalusan produk yaitu 126. Angka indeks persepsi konsumen mengenai kehalusan produk yaitu : $126 / 150 \times 100=84 \%$. Sehingga interpretasi nilainya sangat puas. Ini menunjukkan bahwa konsumen sangat puas dengan kehalusan produk yang dihasilkan oleh BLPT Kaaten. Konsumen berpendapat bahwa produk produk yang dihasilkan oleh BLPT ketika dipegang begitu halus tidak kasar dibandingkan dengan produk-produk furniture yang ada di tempat lain. 


\section{Kekuatan produk}

Produk yang memiliki kekuatan dan tidak mudah rusak sangat mempengaruhi konsumen untuk melakukan proses pembelian. Konsumen akan cenderung memilih produk yang bisa tahan lama dibandingkan dengan produk yang mudah rusak.

Tabel 10. Kekuatan Produk

\begin{tabular}{|c|c|c|c|c|}
\hline $\begin{array}{l}\text { Alternatif } \\
\text { Jawaban }\end{array}$ & $\begin{array}{c}\text { Alternatif } \\
\text { Skor }\end{array}$ & $\begin{array}{l}\text { Jumlah } \\
\text { (orang) }\end{array}$ & $\begin{array}{c}\text { Presentas } \\
\mathrm{e} \\
(\%)\end{array}$ & Total \\
\hline Sangat Puas & 5 & 10 & 33,3 & 50 \\
\hline Puas & 4 & 16 & 53,4 & 64 \\
\hline Ragu - ragu & 3 & 4 & 13,3 & 12 \\
\hline Tidak puas & 2 & - & - & - \\
\hline $\begin{array}{l}\text { Sangat tidak } \\
\text { puas }\end{array}$ & 1 & - & - & - \\
\hline Total & & 30 & 100 & 126 \\
\hline
\end{tabular}

Sumber : Diolah dari data primer, 2017

Tabel 10 menunjukkan bahwa sebanyak 16 orang $(53,4 \%)$ responden puas dengan kekuatan produk yang dihasilkan oleh BLPT Kaaten. 10 orang $(33,3 \%)$ sangat puas dan 4 orang $(13,3 \%)$ ragu- ragu. Total skor yang diperoleh dari 30 responden yaitu 126 , sehingga rata- rata dukungan persepsi konsumen terletak pada daerah setuju. Angka indeks persepsi konsumen mengenai kekuatan produk yaitu: $126 / 150$ x $100=84 \%$. Interpretasi nilainya sangat puas.

Hal ini menunjukkan bahwa sebagian besar konsumen sangat puas dengan kekuatan produk yang dihasilkan oleh BLPT Kaaten dibandingkan dengan produk yang dihasilkan oleh perusahaan lainnya. Konsumen berpendapat bahwa produk -produk BLPT sangat kuat dibuktikan dengan produk-produk BLPT tidak mudah rusak meskipun sudah digunakan dalam jangka waktu yang lama, bahan materialnya tidak rapuh dan sangat tahan lama.

\section{Rekapitulasi Dimensi Mutu Produk terhadap Kinerja (Performance)}

Tabel 11 menunjukkan bahwa terdapat 3 indikator dimensi mutu produk terhadap kinerja dimana pernyataan 1 adalah indeks kepuasan terendah yaitu $82.6 \%$, sedangkan pernyataan ke 2 dan ke 3 mendapat indeks kepuasan yang sama yaitu $84 \%$.
Tabel 11. Rekapitulasi Jumlah Skor Pengambilan Data, Indeks Kepuasan, dan Interpretasi pada Indikator Dimensi Mutu Produk Terhadap Kinerja (Performance)

\begin{tabular}{|c|c|c|c|c|}
\hline No & Pernyataan & $\begin{array}{l}\text { Total } \\
\text { Skor }\end{array}$ & $\begin{array}{c}\text { Indeks } \\
\text { Kepuasan }(\%)\end{array}$ & Interpretasi \\
\hline 1 & $\begin{array}{l}\text { Produk BLPT } \\
\text { Kaaten } \\
\text { didesain rapi. }\end{array}$ & 124 & 82.6 & $\begin{array}{l}\text { Sangat } \\
\text { Puas }\end{array}$ \\
\hline 2 & $\begin{array}{ll}\text { Produk } & \text { BLPT } \\
\text { Kaaten } & \text { sangat } \\
\text { halus. } & \end{array}$ & 126 & 84 & $\begin{array}{l}\text { Sangat } \\
\text { Puas }\end{array}$ \\
\hline 3 & $\begin{array}{l}\text { Produk BLPT } \\
\text { Kaaten sangat } \\
\text { kuat dan tidak } \\
\text { mudah rusak. }\end{array}$ & 126 & 84 & $\begin{array}{l}\text { Sangat } \\
\text { Puas }\end{array}$ \\
\hline & Total Skor & 125,3 & 83,5 & $\begin{array}{l}\text { Sangat } \\
\text { Puas }\end{array}$ \\
\hline
\end{tabular}

\section{Keistimewaan (Features)}

Produk bermutu mempunyai keistimewaan khusus dibandingkan dengan produk lain. Keistimewaan merupakan pernak - pernik yang melengkapi atau meningkatkan fungsi dasar dari sebuah produk. Keistimewaan meliputi desain produk, kelengkapan aksesoris, keseragaman warna dan keseragaman ukuran.

\section{Desain Produk}

Desain produk yang menarik sangat mempengaruhi konsumen dalam memilih suatu produk untuk dikonsumsi. Desain produk juga berkaitan dengan seberapa baik produk tersebut dibuat. Berikut ini tanggapan konsumen mengenai desain produk.

Tabel 12. Desain Produk

\begin{tabular}{lcccc}
\hline $\begin{array}{l}\text { Alternatif } \\
\text { Jawaban }\end{array}$ & $\begin{array}{c}\text { Alternatif } \\
\text { Skor }\end{array}$ & $\begin{array}{c}\text { Jumlah } \\
\text { (orang) }\end{array}$ & $\begin{array}{c}\text { Presentase } \\
(\%)\end{array}$ & $\begin{array}{c}\text { Total } \\
\text { Skor }\end{array}$ \\
\hline Sangat Puas & 5 & 6 & 20 & 30 \\
Puas & 4 & 19 & 63,3 & 76 \\
Ragu - ragu & 3 & 5 & 16,7 & 15 \\
Tidak puas & 2 & - & - & - \\
Sangat tidak puas & 1 & - & - & - \\
\hline \multicolumn{1}{c}{ Total } & & 30 & 100 & 121 \\
\hline
\end{tabular}

Sumber : Diolah dari data primer, 2017

Tabel 12 menunjukkan bahwa sebanyak 19 orang $(63,3 \%)$ responden puas dengan desain produk. 6 orang $(20 \%)$ sangat puas dan 5 orang $(16,7 \%)$ masih ragu-ragu dengan pernyataan mengenai desain produk. Total skor yang diperoleh yaitu 121. Sehingga rata-rata dukungan persepsi konsumen berada pada daerah setuju. Angka indeks persepsi konsumen mengenai desain produk yaitu: $121 / 150 \times 100=80,6 \%$. Ini menunjukkan bahwa sebagian besar konsumen sangat puas 
dengan desain produk yang dihasilkan oleh BLPT Kaaten yang sangat menarik. Konsumen mengatakan bahwa desain produk-produk di BLPT Kaaten sangat menarik dikarenakan konsumen bisa memesan produk berdasarkan kemauan dan keiginan konsumen sendiri. BLPT Kaaten juga selalu menrancang produk dengan mengikuti kemajuan zaman sehingga produk- produk yang dihasilkan merupakan produk - produk terbaru. Dan yang membuat produk tersebut semakin menarik desainnnya menggunakan satu bahan material yaitu pohon kelapa yang sudah tidak produktif lagi.

\section{Kelengkapan Aksesoris}

Produk yang dilengkapi dengan fiturfitur berupa aksesoris akan terlihat lebih menarik dibandingkan dengan produk yang hanya biasa-biasa saja. Semakin menariknya sebuah produk akan semakin mempengaruhi konsumen untuk melakukan proses pembelian. Tanggapan konsumen mengenai kelengkapan aksesoris dapat dilihat pada Tabel 13.

\begin{tabular}{lcccc}
\multicolumn{6}{l}{ Tabel 13. Kelengkapan Aksesoris } \\
\hline $\begin{array}{l}\text { Alternatif } \\
\text { Jawaban }\end{array}$ & $\begin{array}{c}\text { Alternatif } \\
\text { Skor }\end{array}$ & $\begin{array}{c}\text { Jumlah } \\
\text { (orang) }\end{array}$ & $\begin{array}{c}\text { Presentase } \\
(\%)\end{array}$ & $\begin{array}{c}\text { Total } \\
\text { Skor }\end{array}$ \\
\hline Sangat Puas & 5 & 3 & 10 & 15 \\
Puas & 4 & 17 & 56,7 & 68 \\
Ragu - ragu & 3 & 6 & 20 & 18 \\
Tidak puas & 2 & 3 & 10 & 6 \\
Sangat tidak puas & 1 & 1 & 3,3 & 1 \\
\hline Total & \multicolumn{5}{c}{30} \\
\hline Sumber : Diolah dari data & primer, 2017
\end{tabular}

Tabel 13 menunjukkan bahwa sebanyak 17 orang $(56,7 \%)$ responden puas dengan pernyataan mengenai kelengkapan aksesoris. 6 orang $(20 \%)$ ragu- ragu, 3 orang $(10 \%)$ sangat puas, 3 orang $(10 \%)$ tidak puas dan 1 orang $(3,3$ $\%$ ) sangat tidak puas. Total skor yang diperoleh dari total responden 30 orang yaitu 108. Sehingga angka indeks persepsi konsumen mengenai kelengkapan aksesoris yaitu : 108/150 x $100=72$ $\%$. Ini menunjukkan bahwa sebagian besar konsumen puas dengan kelengkapan aksesoris yang ada pada produk yang dihasilkan oleh BLPT Kaaten. Berdasarkan wawancara kepada konsumen, kelengkapan aksesoris yang ada pada produk yang dihasilkan oleh BLPT Kaaten biasanya tergantung pesanan yang diiginkan oleh konsumen. Jika konsumen ingin menambah aksesoris yang ada pada desain akan dikenakan biaya tambahan.

\section{Keseragaman Warna}

Warna merupakan salah satu daya tarik yang terdapat pada suatu produk. Warna yang seragam akan membuat produk menjadi semakin menarik untuk dilihat. Tabel 14 akan menunjukkan tanggapan konsumen mengenai keseragaman warna.

Tabel 14. Keseragaman Warna

\begin{tabular}{lcccc}
\hline $\begin{array}{l}\text { Alternatif } \\
\text { Jawaban }\end{array}$ & $\begin{array}{c}\text { Alternatif } \\
\text { Skor }\end{array}$ & $\begin{array}{c}\text { Jumlah } \\
\text { (orang) }\end{array}$ & $\begin{array}{c}\text { Presentase } \\
(\%)\end{array}$ & $\begin{array}{c}\text { Total } \\
\text { Skor }\end{array}$ \\
\hline Sangat Puas & 5 & 7 & 23,3 & 35 \\
Puas & 4 & 18 & 60 & 72 \\
Ragu - ragu & 3 & 5 & 16,7 & 15 \\
Tidak puas & 2 & - & - & - \\
Sangat tidak puas & 1 & - & - & - \\
\hline Total & & 30 & 100 & 122 \\
\hline
\end{tabular}

Sumber : Diolah dari data primer, 2017

Tabel 14 menunjukkan bahwa sebanyak 18 orang $(60 \%)$ responden puas, 7 orang $(23,3 \%)$ sangat puas dan sebanyak 5 orang $(6,7 \%)$ raguragu dengan keseragaman warna. Total skor yang diperoleh dari 30 responden yaitu. Angka indeks persepsi konsumen mengenai keseragaman warna yaitu: $122 / 150$ x $100=81,3 \%$. Ini menunjukkan bahwa sebagian besar konsumen sangat puas dengan keseragaman warna pada produk yang dihasilkan oleh BLPT Kaaten Tomohon. Konsumen mengatakan bahwa semua produkproduk yang ada di BLPT memiliki warna yang seragam. Tidak ada satupun produk yang didesain dengan warna yang berbeda, hanya menggunakan satu warna.

\section{Keseragaman Ukuran}

Ukuran dari sebuah produk tidak terlalu berpengaruh dalam proses pembelian sebuah produk. Hal ini disebabkan karena masingmasing konsumen memiliki kebutuhan yang berbeda-beda. Ukuran dari sebuah produk biasanya disesuaikan dengan keinginan dari konsumen.

Tabel 15. Keseragaman Ukuran

\begin{tabular}{lcccc}
$\begin{array}{l}\text { Alternatif } \\
\text { Jawaban }\end{array}$ & $\begin{array}{c}\text { Alternatif } \\
\text { Skor }\end{array}$ & $\begin{array}{c}\text { Jumlah } \\
\text { (orang) }\end{array}$ & $\begin{array}{c}\text { Presentase } \\
(\%)\end{array}$ & $\begin{array}{c}\text { Total } \\
\text { Skor }\end{array}$ \\
\hline Sangat Puas & 5 & 6 & 20 & 30 \\
Puas & 4 & 11 & 36,7 & 44 \\
Ragu - ragu & 3 & 9 & 30 & 27 \\
Tidak puas & 2 & 3 & 10 & 6 \\
Sangat tidak puas & 1 & 1 & 3,3 & 1 \\
\hline Total & & 30 & 100 & 108 \\
\hline
\end{tabular}

Sumber : Diolah dari data primer, 2017 
Tabel 15 menunjukkan bahwa sebanyak 11 orang $(36,7 \%)$ puas, 9 orang (30 $\%)$ ragu-ragu, 6 orang $(20 \%)$ sangat puas, 3 orang $(10 \%)$ tidak puas dan 1 orang $(3,3 \%)$ sangat tidak puas dengan pernyataan mengenai keseragaman ukuran. Total skor yang diperoleh yaitu 108. Angka indeks kepuasan konsumen mengenai keseragaman ukuran yaitu 108/150 x $100=72 \%$. Ini menunjukkan bahwa sebagian besar konsumen puas dengan keseragaman ukuran produk yang dihasilkan oleh BLPT Kaaten. Konsumen merasa puas dikarenakan produk-produk di BLPT Kaaten didesain berdasarkan keinginan konsumen, konsumen bisa menentukan ukuran yang diinginkan oleh konsumen. Ada juga konsumen yang menyatakan tidak puas karena ada beberapa pesanan yang tidak sesuai ukurannya dengan apa yang telah dipesan.

\section{Rekapitulasi Dimensi Mutu Produk terhadap Keistimewaan (Features)}

Tabel 16. Rekapitulasi Jumlah Skor Pengambilan Data, Indeks Kepuasan, dan Interpretasi pada Indikator Dimensi Mutu Produk Terhadap Keistimewaan (Features)

\begin{tabular}{|c|c|c|c|c|}
\hline No & Pernyataan & $\begin{array}{l}\text { Total } \\
\text { Skor }\end{array}$ & $\begin{array}{c}\text { Indeks } \\
\text { Kepuasan }(\%)\end{array}$ & Interpretasi \\
\hline 1 & $\begin{array}{l}\text { Desain } \\
\text { produk BLPT } \\
\text { Kaaten } \\
\text { menarik }\end{array}$ & 121 & 80.6 & $\begin{array}{c}\text { Sangat } \\
\text { Puas }\end{array}$ \\
\hline 2 & $\begin{array}{l}\text { Produk BLPT } \\
\text { Kaaten } \\
\text { dilengkapi } \\
\text { dengan } \\
\text { aksesoris. }\end{array}$ & 108 & 72 & Puas \\
\hline 3 & $\begin{array}{l}\text { Produk } \\
\text { BLPT } \\
\text { Kaaten } \\
\text { memiliki } \\
\text { warna yang } \\
\text { seragam. }\end{array}$ & 122 & 81,3 & $\begin{array}{l}\text { Sangat } \\
\text { Puas }\end{array}$ \\
\hline 4 & $\begin{array}{l}\text { Produk } \\
\text { BLPT } \\
\text { Kaaten } \\
\text { memiliki } \\
\text { ukuran yang } \\
\text { seragam. }\end{array}$ & 108 & 72 & Puas \\
\hline & Total Skor & 114,7 & 76,47 & Puas \\
\hline
\end{tabular}

Tabel 16 menunjukkan bahwa terdapat 4 indikator dimensi mutu produk terhadap keistimewaan (features) dimana pernyataan 3 adalah indeks kepuasaann tertinggi yaiu $81,3 \%$, sedangkan pernyataan 1 mendapat indeks 80,6
$\%$, pernyataan 2 mendapat indeks $72 \%$, dan pernyataan 4 mendapat indeks kepuasan $72 \%$.

\section{Keandalan (Reability)}

Keandalan merupakan kemampuan produk untuk bekerja secara memuaskan selama penggunaan yang biasa. Semakin lama produk tersebut digunakan maka produk tersebut memiliki kualitas yang tinggi.

\section{Kemampuan Produk untuk Memuaskan Konsumen}

Sebuah produk bisa dikatakan andal jika produk tesebut mampu memuaskan konsumen selama penggunaan yang biasa. Berikut ini tanggapan konsumen terhadap kemampuan suatu produk yang dapat dilihat pada Tabel 17.

\begin{tabular}{lcccc} 
Tabel 17. $\begin{array}{c}\text { Kemampuan } \\
\text { Konsumen }\end{array}$ & Produk & untuk & Memuaskan \\
\hline Alternatif & Alternatif & Jumlah & Presentase & Total \\
Jawaban & Skor & (orang) & $(\%)$ & Skor \\
Sangat Puas & 5 & 9 & 230 & 45 \\
Puas & 4 & 17 & 56,7 & 68 \\
Ragu - ragu & 3 & 4 & 13,3 & 12 \\
Tidak puas & 2 & - & - & - \\
Sangat tidak & 1 & - & - & - \\
puas & \multicolumn{5}{c}{100} \\
Total \\
Sumber : Diolah dari data primer, 2017 \\
\multicolumn{5}{c}{125} \\
\hline \\
Tabel 17 \\
menunjukkan sebanyak
\end{tabular}
orang $(56,7 \%)$ responden puas, sangat puas sebanyak 9 orang $(30 \%)$, dan sebanyak 4 orang $(13,3 \%)$ masih ragu - ragu. Total skor yang diperoleh yaitu 125. Angka indeks kepuasan mengenai kemampuan produk untuk memuaskan konsumen yaitu : 125/150 x $100=$ $83,3 \%$. Ini menunjukkan bahwa sebagian besar konsumen sangat puas dengan kemampuan produk yang dihasilkan BLPT dalam memuaskan konsumen selama penggunaan yang biasa. Konsumen berpendapat bahwa produk - produk BLPT memiliki keandalan karena produk BLPT bisa bertahan lama lebih dari waktu yang biasanya dan konsumen bisa mendapatkan kepuasan selama menggunakan produk-produk dari BLPT.

\section{Keamanan Produk}

Keamanan suatu produk sangat mempengaruhi penggunaan dari produk tersebut. Hal ini tentunya membuat konsumen seringkali 
berpikir untuk mengkonsumsi produk dilihat dari segi keamanannya. Tabel 18 akan menunjukkan tanggapan konsumen mengenai keamanan dari suatu produk.

Tabel 18. Keamanan Produk

\begin{tabular}{|c|c|c|c|c|}
\hline $\begin{array}{l}\text { Alternatif } \\
\text { Jawaban }\end{array}$ & $\begin{array}{c}\text { Alternatif } \\
\text { Skor }\end{array}$ & $\begin{array}{l}\begin{array}{l}\text { Jumlah } \\
\text { (orang) }\end{array} \\
\text { (orat }\end{array}$ & $\begin{array}{c}\text { Presentase } \\
(\%)\end{array}$ & $\begin{array}{l}\text { Total } \\
\text { Skor }\end{array}$ \\
\hline Sangat Puas & 5 & 9 & 30 & 45 \\
\hline Puas & 4 & 17 & 56,7 & 68 \\
\hline Ragu - ragu & 3 & 4 & 13,3 & 12 \\
\hline Tidak puas & 2 & - & - & - \\
\hline Sangat tidak puas & 1 & - & - & - \\
\hline Total & & 30 & 100 & 125 \\
\hline
\end{tabular}

Tabel 18 menunjukkan sebanyak 17 orang $(56,7 \%)$ responden puas, sangat puas sebanyak 9 orang (30\%), dan sebanyak 4 orang $(13,3 \%)$ masih ragu - ragu. Total skor yang diperoleh yaitu 125 . Angka indeks kepuasan mengenai keamanan dari produk yaitu: $125 / 150$ x $100=83,3 \%$. Ini menunjukkan bahwa sebagian besar konsumen sangat puas dengan keamanan produk yang dihasilkan BLPT Kaaten. Dari hasil wawancara kepada konsumen, konsumen mengatakan bahwa semua produk- produk yang mereka beli di BLPT Kaaten sangat aman untuk digunakan. BLPT Kaaten tidak menggunakan bahan-bahan yang berbahaya ataupun material-material yang dapat membahayakan konsumen.

\section{Rekapitulasi Dimensi Mutu Produk Terhadap Keandalan (Reability)}

Tabel 19 menunjukkan bahwa terdapat 2 indikator dimensi mutu produk terhadap keandalan (reability) dimana pernyataan 1 dan 2 mendapat indeks $83,3 \%$.

\begin{tabular}{|c|c|c|c|c|}
\hline Tabel & $\begin{array}{l}\text { 19. Rekapitulasi } \\
\text { Indeks } \\
\text { Indikator } \\
\text { Keandalan } \\
\end{array}$ & $\begin{array}{c}\text { si Jumlah } \\
\text { Kepuasan, } \\
\text { Dimensi } \\
\text { (Reability }\end{array}$ & $\begin{array}{lr}\text { Skor } & \text { Penga } \\
\text { dan } & \text { Inte } \\
\text { Mutu } & \text { Prod } \\
\text { ) } & \\
\end{array}$ & $\begin{array}{l}\text { nbilan Data, } \\
\text { oretasi pada } \\
k \text { Terhadap }\end{array}$ \\
\hline No & Pernyataan & $\begin{array}{l}\text { Total } \\
\text { Skor }\end{array}$ & $\begin{array}{c}\text { Indeks } \\
\text { Kepuasan } \\
(\%)\end{array}$ & Interpretasi \\
\hline 1 & $\begin{array}{l}\text { Produk BLPT } \\
\text { Kaaten mampu } \\
\text { memuaskan } \\
\text { pelanggan selama } \\
\text { penggunaan yang } \\
\text { biasa. }\end{array}$ & a & 83,3 & Sangat Puas \\
\hline 2 & $\begin{array}{lr}\text { Produk } & \text { BLPT } \\
\text { Kaaten } & \text { aman } \\
\text { untuk digunakan. }\end{array}$ & 125 & 83,3 & Sangat Puas \\
\hline & Total skor & 125 & 83,3 & Sangat Puas \\
\hline
\end{tabular}

\section{Kesesuaian}

Kesesuaian berkaitan dengan tingkat kesesuaian produk terhadap spesifikasi yang telah ditetapkan sebelumnya atau sesuai dengan standarnya. Kesesuaian dari sebuah produk meliputi kesesuaian desain, kesesuaian ukuran dan kesesuaian bahan material yang digunakan.

\section{Kesesuaian Desain}

Mengkonsumsi sebuah produk konsumen akan lebih memilih produk yang bisa memenuhi keinginan dan kebutuhannya, salah satunya yaitu produk yang dihasilkan bisa didesain sesuai dengan keinginan konsumen.

Tabel 20. Kesesuaian Desain

\begin{tabular}{lcccc}
\hline $\begin{array}{c}\text { Alternatif } \\
\text { Jawaban }\end{array}$ & $\begin{array}{c}\text { Alternatif } \\
\text { Skor }\end{array}$ & $\begin{array}{c}\text { Jumlah } \\
\text { (orang) }\end{array}$ & $\begin{array}{c}\text { Presentase } \\
(\%)\end{array}$ & $\begin{array}{c}\text { Total } \\
\text { Skor }\end{array}$ \\
\hline Sangat Puas & 5 & 10 & 33,3 & 50 \\
Puas & 4 & 16 & 53,4 & 64 \\
Ragu - ragu & 3 & 4 & 13,3 & 12 \\
Tidak puas & 2 & - & - & - \\
$\begin{array}{l}\text { Sangat tidak } \\
\text { puas }\end{array}$ & 1 & - & - & - \\
\hline \multicolumn{1}{c}{ Total } & & 30 & 100 & 126 \\
\hline
\end{tabular}

Sumber : Diolah dari data primer, 2017

Tabel 20 menunjukkan bahwa 16 orang $(53,4 \%)$ puas, 10 orang $(33,3 \%)$ sangat puas dan sebanyak 4 orang $(13,3 \%)$ masih ragu- ragu. Total skor yang diperoleh dari 30 responden yaitu 126. Angka indeks kepuasan mengenai kesesuaian desain yaitu: $126 / 150 \times 100=84 \%$. Sehingga interpretasi nilainya tergolong sangat puas. Ini menunjukkan bahwa sebagian besar konsumen sangat puas dengan kesesuaian desain yang dihasilkan oleh BLPT Kaaten. Konsumen sangat puas karena semua desain produk yang ada di BLPT selalu sesuai dengan keinginan konsumen artinya ketika konsumen membeli produk di BLPT Kaaten konsumen bisa mendesain sendiri produk apa yang akan dibeli sesuai dengan keinginan dari konsumen.

\section{Kesesuain Ukuran}

Selain desain yang sesuai dengan keinginan konsumen, kesesuain ukuran juga merupakan salah satu faktor penentu dalam konsumen memilih suatu produk untuk 
dikonsumsi. Pernyataan mengenai kesesuaian ukuran dapat dilihat pada Tabel 21.

Tabel 21. Kesesuain Ukuran

\begin{tabular}{|c|c|c|c|c|}
\hline $\begin{array}{l}\text { Alternatif } \\
\text { Jawaban }\end{array}$ & $\begin{array}{c}\text { Alternatif } \\
\text { Skor }\end{array}$ & $\begin{array}{l}\text { Jumlah } \\
\text { (orang) }\end{array}$ & $\begin{array}{c}\text { Presentase } \\
(\%)\end{array}$ & $\begin{array}{l}\text { Total } \\
\text { Skor }\end{array}$ \\
\hline Sangat & 5 & 9 & 30 & 45 \\
\hline Puas & & & & \\
\hline Puas & 4 & 17 & 56,7 & 68 \\
\hline Ragu - ragu & 3 & 4 & 13,3 & 12 \\
\hline Tidak puas & 2 & - & - & - \\
\hline $\begin{array}{l}\text { Sangat } \\
\text { tidak puas }\end{array}$ & 1 & - & - & - \\
\hline Total & & 30 & 100 & 125 \\
\hline $\begin{array}{r}\text { Sumber : D } \\
\text { Tal }\end{array}$ & $\begin{array}{r}\operatorname{ari} d \\
21\end{array}$ & $\begin{array}{l}\text { primer } \\
\text { menur }\end{array}$ & $\begin{array}{l}017 \\
\text { dkkan }\end{array}$ & ahwa \\
\hline
\end{tabular}

sebanyak 17 orang $(56,7 \%)$ puas, sebanyak 9 orang $(30 \%)$ sangat puas dan 4 orang $(13,3$ $\%)$ masih ragu-ragu. Total skor yang diperoleh yaitu 125. Angka indeks kepuasan konsumen mengenai kesesuian ukuran yaitu : $125 / 150 \times 100=83,3 \%$. Hal ini menunjukkan bahwa sebagian besar konsumen sangat puas dengan kesesuaian ukuran dari produk yang dihasilkan oleh BLPT Kaaten. Selain desain yang disesuaikan dengan keinginan konsumen, ukuran produk yang ada di BLPT Kaaten juga selalu disesuaikan dengan keinginan konsumen.

\section{Kesesuaian Bahan Material}

Bahan material yang digunakan untuk memproduksi suatu produk harus sesuai dengan standarnya. Berikut tanggapan konsumen mengenai kesesuaian bahan material dapat dilihat pada Tabel 22.

Tabel 22. Kesesuaian Bahan Material

\begin{tabular}{lcccc}
\hline $\begin{array}{c}\text { Alternatif } \\
\text { Jawaban }\end{array}$ & $\begin{array}{c}\text { Alternatif } \\
\text { Skor }\end{array}$ & $\begin{array}{c}\text { Jumlah } \\
\text { (orang) }\end{array}$ & $\begin{array}{c}\text { Presentase } \\
(\%)\end{array}$ & $\begin{array}{c}\text { Total } \\
\text { Skor }\end{array}$ \\
\hline Sangat Puas & 5 & 11 & 36,7 & 55 \\
Puas & 4 & 14 & 46,6 & 56 \\
Ragu - ragu & 3 & 5 & 16,7 & 15 \\
Tidak puas & 2 & - & - & - \\
$\begin{array}{l}\text { Sangat tidak } \\
\text { puas }\end{array}$ & 1 & - & - & - \\
\hline \multicolumn{1}{c}{ Total } \\
Sumber : Diolah dari data primer, 2017
\end{tabular}

Tabel 22 menunjukkan sebanyak 14 orang $(46,6 \%)$ puas, 11 orang $(36,7 \%)$ sangat puas dan 5 orang $(16,7 \%)$ masih ragu-ragu. Total skor yang diperoleh 126. Angka indeks kepuasan yang diperoleh yaitu : 126/150 x 100 $=84 \%$. Ini menunjukkan bahwa sebagian besar konsumen sangat puas dengan kesesuaian bahan material yang digunakan oleh BLPT Kaaten. BLPT Kaaten menggunakan satu bahan material yang utama yaitu pohon kelapa. Dalam membuat produk - produk furniture BLPT Kaaten menggunakan pohon kelapa yang sudah tidak produktif lagi dan juga memiliki standar (kriteria khusus) yang sudah ditentukan oleh BLPT sendiri.

\section{Rekapitulasi Dimensi Mutu Terhadap Kesesuaian}

Tabel 23 menunjukkan bahwa terdapat 3 indikator dimensi mutu produk terhadap kesesuaian dimana pernyataan 1 dan 3 mendapat indeks kepuasan tertinggi yaitu $84 \%$ dan pernyataan 2 mendapat indeks $83,3 \%$.

Tabel 23. Rekapitulasi Jumlah Skor Pengambilan Data, Indeks Kepuasan, dan Interpretasi pada Indikator Dimensi Mutu Produk Terhadap Kesesuaian

\begin{tabular}{|c|c|c|c|c|}
\hline No & Pernyataan & $\begin{array}{l}\text { Total } \\
\text { Skor }\end{array}$ & $\begin{array}{c}\text { Indeks } \\
\text { Kepuasan } \\
(\%)\end{array}$ & Interpretasi \\
\hline 1 & $\begin{array}{l}\text { Produk BLPT } \\
\text { memiliki } \\
\text { desain sesuai } \\
\text { dengan } \\
\text { keinginan } \\
\text { konsumen. }\end{array}$ & 126 & 84 & $\begin{array}{l}\text { Sangat } \\
\text { Puas }\end{array}$ \\
\hline 2 & $\begin{array}{l}\text { Produk BLPT } \\
\text { Kaaten } \\
\text { memiliki } \\
\text { ukuran sesuai } \\
\text { dengan } \\
\text { kebutuhan } \\
\text { konsumen. }\end{array}$ & 125 & 83,3 & $\begin{array}{l}\text { Sangat } \\
\text { Puas }\end{array}$ \\
\hline 3 & $\begin{array}{l}\text { Material yang } \\
\text { digunakan } \\
\text { BLPT sesuai } \\
\text { dengan } \\
\text { standarnya. }\end{array}$ & 126 & 84 & $\begin{array}{l}\text { Sangat } \\
\text { Puas }\end{array}$ \\
\hline & Total Skor & 125,6 & 83,7 & $\begin{array}{l}\text { Sangat } \\
\text { Puas }\end{array}$ \\
\hline
\end{tabular}

Sumber : Diolah dari data primer, 2017

\section{Daya Tahan (Durability)}

Daya tahan berkaitan dengan rentang kehidupan produk atau ukuran masa pakai suatu produk. Semakin lama produk tersebut digunakan maka produk tersebut berkualitas. Pelanggan akan memandang suatu produk berkualitas jika 
produk memiliki daya tahan dalam pemakaian. Daya tahan suatu produk meliputi: daya tahan cat warna, daya tahan material dan daya tahan aksesoris.

\section{Daya Tahan Cat Warna}

Produk-produk furniture biasanya dilengkapi dengan cat warna yang bervariasi. Warna juga menjadi salah satu penentu menariknya suatu produk. Produk yang memiliki daya tahan cat warna akan semakin menarik.

Tabel 24. Daya Tahan Cat Warna

\begin{tabular}{ccccc}
\hline $\begin{array}{c}\text { Alternatif } \\
\text { Jawaban }\end{array}$ & $\begin{array}{c}\text { Alternatif } \\
\text { Skor }\end{array}$ & $\begin{array}{c}\text { Jumlah } \\
\text { (orang) }\end{array}$ & $\begin{array}{c}\text { Presentase } \\
(\%)\end{array}$ & $\begin{array}{c}\text { Total } \\
\text { Skor }\end{array}$ \\
\hline Sangat Puas & 5 & 6 & 20 & 30 \\
Puas & 4 & 20 & 66,7 & 80 \\
Ragu - ragu & 3 & 4 & 13,3 & 12 \\
Tidak puas & 2 & - & - & - \\
Sangat tidak & 1 & - & - & - \\
puas & & & & \\
\hline Total & & 30 & 100 & 122 \\
\hline
\end{tabular}

Sumber : Diolah dari data primer, 2017

Tabel 24 menunjukkan bahwa 20 orang $(66,7 \%)$ puas, 6 orang $(20 \%)$ sangat puas dan 4 orang $(13,3 \%)$ masih ragu-ragu. Total skor yang diperoleh 122. Angka indeks kepuasan konsumen terhadap daya tahan cat warna yaitu : $122 / 150 \times 100=81,3 \%$. Ini menunjukkan bahwa sebagian besar konsumen sangat puas dengan daya tahan cat warna dari produk yang dihasilkan oleh BLPT Kaaten yang tidak mudah pudar dan tahan lama dibandingkan dengan produk furniture lainnya.

\section{Daya Tahan Material}

Selain warna daya tahan material juga sangat penting pada suatu produk. Semakin kuat bahan material yang dipakai maka semakin berkualitas produk tersebut.

\begin{tabular}{lllll}
\multicolumn{6}{l}{ Tabel 25. Daya Tahan } & Material \\
\hline $\begin{array}{l}\text { Alternatif } \\
\text { Jawaban }\end{array}$ & $\begin{array}{l}\text { Alternatif } \\
\text { Skor }\end{array}$ & $\begin{array}{c}\text { Jumlah } \\
\text { (orang) }\end{array}$ & $\begin{array}{c}\text { Presentase } \\
(\%)\end{array}$ & $\begin{array}{l}\text { Total } \\
\text { Skor }\end{array}$ \\
\hline Sangat puas & 5 & 9 & 30 & 45 \\
Puas & 4 & 18 & 60 & 72 \\
Ragu - ragu & 3 & 3 & 10 & 99 \\
Tidak puas & 2 & - & - & - \\
Sangat tidak & 1 & - & - & - \\
puas & \multicolumn{5}{l}{} \\
\hline Total & & & \\
\hline Sumber : Diolah dari data primer, 2017.
\end{tabular}

Tabel 25 menunjukkan bahwa sebanyak 18 orang $(60 \%)$ puas, 9 orang $(30 \%)$ sangat puas dan 3 orang $(10 \%)$ masih ragu-ragu. Total skor yang diperoleh 126 . Angka indeks kepuasan konsumen mengenai daya tahan material yaitu : $126 / 150 \times 100=$ $84 \%$. Hal ini menunjukkan bahwa sebagian besar konsumen sangat puas dengan daya tahan material dari produk yang dihasilkan oleh BLPT Kaaten yang tidak mudah rapuh.

\section{Daya Tahan Aksesoris}

Daya tahan aksesoris juga merupakan nilai tambah dari suatu produk. Semakin tahan aksesoris yang ada pada suatu produk maka semakin berkualitas produk tersebut.

Tabel 26. Daya Tahan Aksesoris

\begin{tabular}{ccccc}
\hline $\begin{array}{c}\text { Alternatif } \\
\text { Jawaban }\end{array}$ & $\begin{array}{c}\text { Alternatif } \\
\text { Skor }\end{array}$ & $\begin{array}{c}\text { Jumlah } \\
\text { (orang) }\end{array}$ & $\begin{array}{c}\text { Presentase } \\
(\%)\end{array}$ & $\begin{array}{c}\text { Total } \\
\text { Skor }\end{array}$ \\
\hline Sangat Puas & 5 & 4 & 13,3 & 20 \\
Puas & 4 & 19 & 63,4 & 76 \\
Ragu - ragu & 3 & 7 & 23,3 & 21 \\
Tidak puas & 2 & - & - & - \\
$\begin{array}{c}\text { Sangat tidak } \\
\text { puas }\end{array}$ & 1 & - & - & - \\
\hline Total & & & & \\
\hline
\end{tabular}

Sumber : Diolah dari data primer, 2017

Tabel 26 menunjukkan bahwa 19 orang $(63,4 \%)$ puas, 7 orang $(23,3 \%)$ ragu-ragu dan sebanyak 4 orang (13,3\%) sangat puas. Total skor yang diperoleh yaitu 117. Angka indeks kepuasan mengenai daya tahan aksesoris yaitu: $117 / 150 \times 100=78 \%$. Ini menunjukkan bahwa sebagian besar konsumen puas dengan daya tahan aksesoris yang ada pada produk yang dihasilkan oleh BLPT Kaaten karena tidak mudah lepas.

\section{Rekapitulasi Dimensi Mutu Produk Terhadap Daya Tahan (Durability)}

Tabel 27 menunjukkan bahwa ada 3 indikator dimensi mutu produk terhadap daya tahan (durability) dimana pernyataan 2 mendapat indeks tertinggi yaitu $84 \%$. Sedangkan pernyataan 1 mendapat indeks $81,3 \%$ dan pernyataan 3 mendapat indeks $78 \%$. 


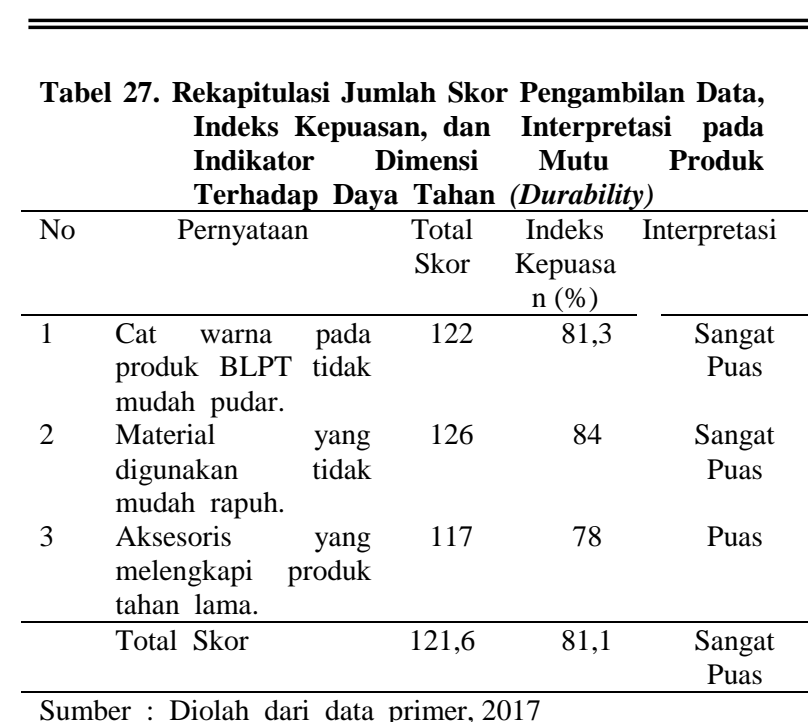

\section{Kemudahan Perbaikan}

Produk bermutu baik harus pula memenuhi kemudahan untuk diperbaiki atau dirawat. Dimensi ini merupakan ukuran mudahnya dirawat sehingga produk tersebut dapat beroperasi dengan baik.

\begin{tabular}{lcccc}
\multicolumn{6}{l}{ Tabel 28. Kemudahan Perbaikan } \\
\hline $\begin{array}{c}\text { Alternatif } \\
\text { Jawaban }\end{array}$ & $\begin{array}{c}\text { Alternatif } \\
\text { Skor }\end{array}$ & $\begin{array}{c}\text { Jumlah } \\
\text { (orang) }\end{array}$ & $\begin{array}{c}\text { Presentase } \\
(\%)\end{array}$ & $\begin{array}{c}\text { Total } \\
\text { Skor }\end{array}$ \\
\hline Sangat Puas & 5 & 3 & 10 & 15 \\
Puas & 4 & 24 & 80 & 96 \\
Ragu - ragu & 3 & 3 & 10 & 9 \\
Tidak puas & 2 & - & - & - \\
Sangat tidak & 1 & - & - & - \\
puas & \multicolumn{5}{l}{100} \\
\hline Total \\
Sumber : Diolah dari data primer, 2017
\end{tabular}

Tabel 28 menunjukkan bahwa sebanyak 24 orang $(80 \%)$ puas, sedangkan sebanyak 3 orang $(10 \%)$ sangat puas dan ragu-ragu. Total skor yang diperoleh yaitu 120. Angka indeks kepuasan mengenai kemudahan perbaikan yaitu: $120 / 150 \times 100=80 \%$. Ini menunjukkan bahwa sebagian besar konsumen puas dengan kemudahan perbaikan dari produk yang dihasilkan oleh BLPT Kaaten. Konsumen berpendapat bahwa produk- produk BLPT mudah untuk dirawat dan diperbaiki.

\section{Rekapitulasi Dimensi Mutu Produk Terhadap Kemudahan Perbaikan}

Tabel 29 menunjukkan terdapat 1 indikator dimensi mutu produk terhadap kemudahan perbaikan dimana mendapat indeks $80 \%$.
Tabel 29. Rekapitulasi Jumlah Skor Pengambilan Data, Indeks Kepuasan, dan Interpretasi pada Indikator Dimensi Mutu Produk Terhadap Kemudahan Perbaikan

\begin{tabular}{llccc}
\hline No & Pernyatan & $\begin{array}{c}\text { Total } \\
\text { Skor }\end{array}$ & $\begin{array}{c}\text { Indeks } \\
\text { Kepuasan } \\
(\%)\end{array}$ & Interpretasi \\
\hline 1 & $\begin{array}{l}\text { Jika produk yang } \\
\text { dihasilkan oleh }\end{array}$ & & 80 & Puas \\
& BLPT Kaaten & & \\
& rusak mudah & & \\
& untuk diperbaiki. & & \\
\hline Sumber : Diolah dari data primer, 2017 &
\end{tabular}

Sumber : Diolah dari data primer, 2017

\section{Keindahan}

Penampilan fisik dari suatu produk merupakan salah satu daya tarik untuk menarik perhatian konsumen. Keindahan berkaitan dengan bagaimana produk tersebut dilihat dan dirasakan. Keindahan suatu produk meliputi : tampilan produk, tampilan warna, dan penggunaan material.

\section{Tampilan Produk}

Tampilan produk adalah salah satu faktor keindahan suatu produk. Semakin indah suatu produk maka semakin menarik produk tersebut.

\begin{tabular}{ccccc} 
Tabel 30. Tampilan Produk & & & \\
\hline $\begin{array}{c}\text { Alternatif } \\
\text { Jawaban }\end{array}$ & $\begin{array}{c}\text { Alternatif } \\
\text { Skor }\end{array}$ & $\begin{array}{c}\text { Jumlah } \\
\text { (orang) }\end{array}$ & $\begin{array}{c}\text { Presentase } \\
(\%)\end{array}$ & $\begin{array}{c}\text { Total } \\
\text { Skor }\end{array}$ \\
\hline Sangat Puas & 5 & 7 & 23,3 & 35 \\
Puas & 4 & 20 & 66,7 & 80 \\
Ragu - ragu & 3 & 3 & 10 & 9 \\
Tidak puas & 2 & - & - & - \\
Sangat tidak & 1 & - & - & - \\
puas & & & & \\
\hline Total & & 30 & 100 & 124
\end{tabular}

Sumber : Diolah dari data primer, 2017

Tabel 30 menunjukkan sebanyak 20 orang $(66,7 \%)$ puas, 7 orang $(23,3 \%)$ sangat puas dan 3 orang $(10 \%)$ masih ragu - ragu. Total skor yang diperoleh yaitu 124. Angka indeks kepuasan mengenai tampilan produk yaitu : $124 / 150 \times 100=82,6 \%$. Ini menunjukkan bahwa sebagian besar konsumen puas dengan tampilan produk yang dihasilkan oleh BLPT Kaaten. Produk - produk BLPT selalu terlihat menarik dari tampilannya saja produk BLPT sangat rapi dan juga halus.

\section{Tampilan Warna}

Warna adalah salah satu elemen yang membuat semakin menariknya sebuah produk. 
Dengan adanya warna akan semakin menambah keindahan dari sebuah produk. Selain itu warna juga sangat mempengaruhi konsumen dalam membeli sebuah produk. Ada konsumen yang akan membeli produk hanya karena sebuah warna yang adalah kesukaannya. Berikut ini tanggapan konsumen mengenai tampilan warna dari produk-produk BLPT.

\begin{tabular}{ccccc} 
Tabel 31. Tampilan Warna \\
$\begin{array}{c}\text { Alternatif } \\
\text { Jawaban }\end{array}$ & $\begin{array}{c}\text { Alternatif } \\
\text { Skor }\end{array}$ & $\begin{array}{c}\text { Jumlah } \\
\text { (orang) }\end{array}$ & $\begin{array}{c}\text { Presentase } \\
(\%)\end{array}$ & $\begin{array}{c}\text { Total } \\
\text { Skor }\end{array}$ \\
\hline Sangat Puas & 5 & 9 & 30 & 45 \\
Puas & 4 & 18 & 60 & 72 \\
Ragu - ragu & 3 & 3 & 10 & 9 \\
Tidak puas & 2 & - & - & - \\
Sangat tidak & 1 & - & - & - \\
puas & & & & \\
\hline Total & & 30 & 100 & 126 \\
\hline
\end{tabular}

Sumber : Diolah dari data primer, 2017

Tabel 31 menunjukkan bahwa sebanyak 18 orang $(60 \%)$ puas, 9 orang (30 $\%)$ sangat puas dan sebanyak 3 orang $(10 \%)$ masih ragu-ragu. Total skor yang diperoleh yaitu 126. Angka indeks kepuasan mengenai tampilan warna yaitu : $126 / 150 \times 100=84 \%$. Ini menunjukkan bahwa sebagian besar konsumen sangat puas dengan tampilan warna dari produk yang dihasilkan oleh BLPT Kaaten. Konsumen sangat puas karena warna yang digunakan pada produk - produk BLPT Kaaten hanya menggunakan satu variasi warna sehingga semua produk memiliki warna yang sama. Selain itu, semua produk menggunakan vernis sehingga serat kayu kelapa bisa terlihat dengan jelas yang bisa membuat produk tersebut semakin menarik untuk dilihat.

\section{Penggunaan Material}

Material yang digunakan dalam membuat suatu produk harus sesuai dengan standarnya. Penggunaan material juga sangat menentukan kualitas produk yang akan dihasilkan. Berikut ini tanggapan konsumen mengenai penggunaan material yang digunakan BLPT Kaaten.

Tabel 32 menunjukkan sebanyak 20 orang $(66,7 \%)$ puas, 7 orang $(23,3 \%)$ sangat puas dan 3 orang $(10 \%)$ masih meragukan mengenai penggunaan material. Total skor yang diperoleh 124. Angka indeks kepuasan yaitu : $124 / 150$ x $100=82,6 \%$. Ini menunjukkan bahwa sebagian besar konsumen sangat puas dengan penggunaan material yang digunakan oleh BLPT Kaaten menggunakan satu bahan material yaitu pohon kelapa yang sudah tidak produktif lagi dan memiliki kriteria khusus (standar) yang telah ditentukan oleh BLPT Kaaten.

\begin{tabular}{ccccc} 
Tabel 32. Penggunaan Material \\
\hline $\begin{array}{c}\text { Alternatif } \\
\text { Jawaban }\end{array}$ & $\begin{array}{c}\text { Alternatif } \\
\text { Skor }\end{array}$ & $\begin{array}{c}\text { Jumlah } \\
\text { (orang) }\end{array}$ & $\begin{array}{c}\text { Presentase } \\
(\%)\end{array}$ & $\begin{array}{c}\text { Total } \\
\text { Skor }\end{array}$ \\
\hline Sangat Puas & 5 & 7 & 23,3 & 35 \\
Puas & 4 & 20 & 66,7 & 80 \\
Ragu - ragu & 3 & 3 & 10 & 9 \\
Tidak puas & 2 & - & - & - \\
Sangat tidak & 1 & - & - & - \\
puas & \multicolumn{5}{c}{30} \\
\hline Total & 100 \\
\hline Sumber : Diolah dari data primer, 2017
\end{tabular}

\section{Rekapitulasi Dimensi Mutu Produk Terhadap Keindahan}

Tabel 33 menunjukkan bahwa terdapat 3 indikator dimensi mutu produk terhadap keindahan dimana pernyataan 2 mendapat indeks $84 \%$, sedangkan pernyataan 1 dan 3 mendapat indeks $82,6 \%$.

\section{Persepsi terhadap Kualitas}

Persepsi terhadap kualitas merupakan kesan kualitas suatu produk yang dirasakan oleh konsumen. Biasanya dimensi ini didasarkan pada citra atau reputasi dari produk tersebut. Tabel 34 menunjukkan bahwa sebanyak 15 orang $(50 \%)$ puas, 9 orang (30\%) sangat puas dan sebanyak 6 orang $(20 \%)$ masih ragu-ragu. Total skor yang diperoleh yaitu 123 . Angka indeks kepuasan mengenai persepsi terhadap kualitas yaitu : $123 / 150 \times 100=82 \%$. Ini menunjukkan bahwa sebagian besar konsumen sangat puas dengan kualitas produk.

\section{Rekapitulasi Dimensi Mutu Produk dari Persepsi Terhadap Kualitas}

Tabel 35 menunjukkan bahwa terdapat 1 indikator dimensi mutu produk dari persepsi terhadap kualitas dimana mendapat indeks $82 \%$.

Rekapitulasi Indeks Persepsi Kepuasan pada Masing-masing Indikator dan Interpretasi Hasil 
Penelitian mengukur kepuasan konsumen terhadap dimensi mutu produk yang diterapkan mengambil 20 indikator sebagai tolok ukur dalam penelitian ini, dimana masing-masing terbagi dalam 8 (delapan) bagian yaitu kinerja (performance), keistimewaan (features), keandalan (reability), kesesuaian, daya tahan (durability), kemudahan perbaikan, keindahan, dan persepsi terhadap kualitas. Untuk mengetahui letak kepuasan konsumen terhadap dimensi mutu produk maka perlu dihitung jumlah keseluruhan skor pada setiap kriterium, dimana sesuai hasil penelitian ini skor mencapai 2.569. Pada penelitian ini, jumlah skor ideal (skor tertinggi) yaitu 3000 (tinggi) dan jumlah skor terendah yaitu 600 (rendah). Berdasarkan data yang dihimpun dari 20 instrumen pernyataan yang diajukan kepada 30 responden, maka diperoleh total 3000, dengan letak indeks ditentukan berdasarkan skala likert:

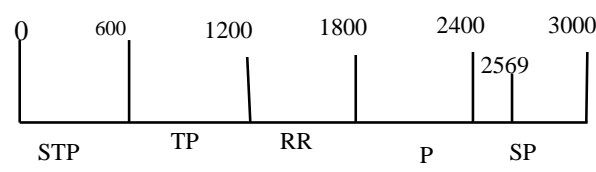

Berdasarkan skala diatas, secara kontinum dapat dilihat bahwa kepuasan konsumen terhadap dimensi mutu produk terletak pada daerah sangat puas. Secara presentase, angka indeks persepsi kepuasan konsumen terhadap dimensi mutu produk yang dihasilkan oleh BLPT terletak pada:

Tingkat Kepuasan Konsumen=Jumlah Skor Hasil Pengumpulan Data X 100\%

Jumlah Skor Ideal (tertinggi)

Tingkat Kepuasan Konsumen $=\underline{2569} \times 100 \%=85,63 \%$ 3000

Dengan interpretasi nilai:

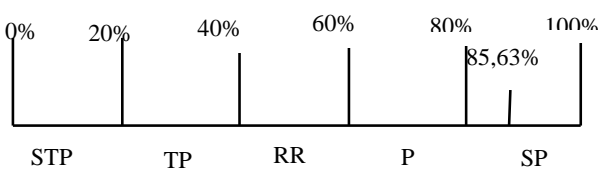

Berdasarkan hasil analisis menggunakan skala likert, maka dapat diketahui bahwa angka indeks persepsi kepuasan konsumen terhadap dimensi mutu produk BLPT Kaaten berada pada titik 85,63 \% dan tergolong sangat puas. Setiap konsumen memiliki sikap, motif, pengalaman masa lalu dan harapan yang berbeda dalam mengkonsumsi produk yang dihasilkan oleh BLPT Kaaten. Dari hasil wawancara kepada konsumen menunjukkan bahwa dalam pembelian produk, konsumen memilih produk furniture berdasarkan dimensi mutu dari produk tersebut, yaitu kinerja, keistimewaan, keandalan, kesesuaian, daya tahan, kemudahan perbaikan, keindahan dan persepsi terhadap kualitas. Dari hasil wawancara jenis produk yang paling banyak dibeli yaitu meja makan dan kursi tamu. Hal ini membuktikan bahwa konsumen membeli barang berdasarkan kebutuhan masing masing. Hasil wawancara juga menunjukkan bahwa responden dalam membeli produk selain berdasarkan kualitas (mutu) dari produk, sebagian responden juga mempertimbangkan harga dari produk tersebut. Target atau objek dari penelitian ini yaitu konsumen yang membeli produk yang dihasilkan oleh BLPT Kaaten. Konsumen pada saat membeli produk produk di BLPT mengaku tidak keberatan membayar mahal jika sepadan dengan mutu (kualitas) dari produk tersebut. Hasil penelitian diperoleh bahwa secara keseluruhan persepsi kepuasan konsumen terhadap dimensi mutu produk adalah sangat puas, artinya konsumen produk furniture BLPT Kaaten menyadari akan keunggulan dari produk yang dihasilkan oleh BLPT Kaaten dalam hal kualitas. Namun ada beberapa alasan yang menghambat konsumen untuk membeli produk di BLPT antara lain: Harga produk yang dihasilkan oleh BLPT Kaaten cenderung lebih mahal dibandingkan dengan produk furniture yang dihasilkan oleh perusahaan furniture lainnya, sehingga perilaku konsumen yang cenderung lebih memilih produk yang lebih murah, meskipun sebagian besar konsumen merasa bahwa harga produk di BLPT masih bisa dijangkau.

1. Lokasi yang jauh dari keramaian sehingga membuat konsumen kurang bisa menjangkau lokasi BLPT.

2. Walaupun konsumen sudah menyadari keunggulan dari produk - produk yang dihasilkan oleh BLPT Kaaten, namun konsumen juga akan membeli produk berdasarkan kebutuhannya. Artinya konsumen hanya akan membeli produk yang belum ada pada konsumen. 
Tabel 33. Rekapitulasi Jumlah Skor Pengambilan Data, Indeks Kepuasan, dan Interpretasi pada Indikator Dimensi Mutu Produk Terhadap Keindahan

\begin{tabular}{llllcr}
\hline No & \multicolumn{1}{c}{ Pernyatan } & Total Skor & Indeks Kepuasan (\%) & Interpretasi \\
\hline 1 & Tampilan produk BLPT menarik & & Sangat Puas \\
2 & $\begin{array}{l}\text { Produk yang dihasilkan BLPT memiliki warna yang } \\
\text { khas. }\end{array}$ & 126 & 84 & Sangat Puas \\
3 & $\begin{array}{l}\text { Semua produk yang dihasilkan menggunakan satu bahan } \\
\text { material yaitu pohon kelapa. }\end{array}$ & 124 & 82,6 \\
\hline
\end{tabular}

Tabel 34. Persepsi terhadap kualitas

\begin{tabular}{ccccc}
\hline Tabel 34. Persepsi terhadap kualitas & & & Presentase (\%) \\
\hline Alternatif Jawaban & Alternatif Skor & Jumlah (orang) & 30 & Total Skor \\
Sangat Puas & 5 & 9 & 50 & 60 \\
Puas & 4 & 15 & 20 & - \\
Ragu - ragu & 3 & 6 & - & - \\
Tidak puas & 2 & - & - & 100 \\
Sangat tidak puas & 1 & 30 & 123 \\
\hline Total & &
\end{tabular}

Sumber : Diolah dari data primer, 2017

Tabel 35. Rekapitulasi Jumlah Skor Pengambilan Data, Indeks Kepuasan, dan Interpretasi pada Indikator Dimensi Mutu Produk dari Persepsi Terhadap Kualitas

\begin{tabular}{lllccc}
\hline No & \multicolumn{1}{c}{ Produk dari Persepsi Terhadap Kualitas } & Total Skor & Indeks Kepuasan (\%) & Interpretasi \\
\hline 1 & $\begin{array}{l}\text { Produk } \\
\text { karena } \\
\text { lainnya. }\end{array}$ & \multicolumn{1}{c}{ BLPT sudah sangat popular dikalangan masyarakat } & 123 & Sangat Puas \\
& & & \\
\hline
\end{tabular}

Tabel 36. Rekapitulasi Total Skor, Indeks Kepuasan dan Interpretasi Nilai

\begin{tabular}{|c|c|c|c|c|}
\hline No & Pernyataan & Total Skor & Indeks Kepuasan (\%) & Interpretasi \\
\hline \multirow[t]{5}{*}{1} & Kinerja (Performance) & & & \\
\hline & a. Kerapihan & 124 & 82,6 & Sangat Puas \\
\hline & b. Kehalusan & 126 & 84 & Sangat Puas \\
\hline & c. Kekuatan & 126 & 84 & Sangat Puas \\
\hline & Total skor kinerja & 125,3 & 83,5 & Sangat Puas \\
\hline \multirow[t]{6}{*}{2} & Keistimewaan (Features) & & & \\
\hline & a. Desain produk & 121 & 80,6 & Sangat Puas \\
\hline & b. Kelengkapan aksesoris & 108 & 72 & Puas \\
\hline & c. Keseragaman warna & 122 & 81,3 & Sangat Puas \\
\hline & d. Keseragaman ukuran & 108 & 72 & Puas \\
\hline & Total skor keistimewaan & 114,7 & 76,47 & Puas \\
\hline \multirow[t]{4}{*}{3} & Keandalan (Reability) & & & \\
\hline & a. Kemampuan produk & 125 & 83,3 & Sangat Puas \\
\hline & b. Keamanan produk & 125 & 83,3 & Sangat Puas \\
\hline & Total skor keandalan & 125 & 83,3 & Sangat Puas \\
\hline \multirow[t]{6}{*}{4} & Kesesuaian & & & \\
\hline & a. Kesesuaian desain & 126 & 84 & Sangat Puas \\
\hline & b. Kesesuaian ukuran & 125 & 83,3 & Sangat Puas \\
\hline & c. Kesesuaian bahan material & 126 & 84 & Sangat Puas \\
\hline & Total skor kesesuaian & & & Sangat Puas \\
\hline & & 125,6 & 83,7 & \\
\hline \multirow[t]{5}{*}{5} & Daya tahan (Durability) & & & \\
\hline & a. Daya tahan cat warna & 122 & 81,3 & Sangat Puas \\
\hline & b. Daya tahan material & 126 & 84 & Sangat Puas \\
\hline & c. Daya tahan aksesoris & 117 & 78 & Puas \\
\hline & Total skor daya tahan & 121,6 & 81,1 & Sangat Puas \\
\hline 6 & Kemudahan perbaikan & 120 & 80 & Sangat Puas \\
\hline \multirow[t]{5}{*}{7} & Keindahan & & & \\
\hline & a. Tampilan produk & 124 & 82,6 & Sangat Puas \\
\hline & b. Tampilan warna & 126 & 84 & Sangat Puas \\
\hline & c. Penggunaan material & 124 & 82,6 & Sangat Puas \\
\hline & Total skor keindahan & 124,6 & 83 & Sangat Puas \\
\hline 8 & Persepsi terhadap kualitas & 123 & 82 & Sangat Puas \\
\hline
\end{tabular}

Sumber : Diolah dari data primer, 2017 


\section{KESIMPULAN DAN SARAN}

\section{Kesimpulan}

Kepuasan konsumen terhadap dimensi mutu produk BLPT Kaaten Tomohon dari segi kinerja, keistimewaan, keandalan, kesesuaian, daya tahan, kemudahan perbaikan, keindahan dan persepsi terhadap kualitas mencapai total skor pengambilan data 2.569 yang menunjukkan angka indeks kepuasan konsumen sebesar $85,63 \%$ dan tergolong sangat puas. Hal ini menunjukkan bahwa konsumen dari produk produk yang dihasilkan oleh BLPT sangat puas dengan mutu (kualitas) dari produk- produk furniture yang dihasilkan BLPT Kaaten yang dilihat dari dimensi mutu produk. Walaupun ada sebagaian konsumen yang masih belum terlalu puas dikarenakan berbagai faktor yang mempengaruhi presepsi konsumen tersebut.

Untuk meningkatkan kepuasan konsumen terhadap dimensi mutu produk yang dihasilkan oleh BLPT Kaaten Tomohon, pihak BLPT harus memperhatikan dan meningkatkan keseluruhan dimensi mutu produk yaitu kinerja, keistimewaan, keandalan, kesesuaian, daya tahan, kemudahan perbaikan, keindahan dan persepsi terhadap kualitas sesuai dengan harapan dan keinginan dari konsumen.

\section{DAFTAR PUSTAKA}

Arifin. 2009. Manajemen Mutu Terpadu dalam Penerapan Sistem Manajemen Mutu ISO 9001 : 2000 di BLPT Yogyakarta. Fakultas Teknik Universitas Negeri Yogyakarta .

Assauri, Sofyan. 2009. Manajemen Pemasaran. Jakarta : Rajagrafindo.

Budi. 2011. Pengaruh Kualitas Produk Terhadap Kepuasan, reputasi merek dan Loyalitas Konsumen Jamu Tolak Angin PT. Sido Muncul. Skripsi Program studi manajemen Institut Bisnis \& Informatika Indonesia (IBII).

Dale. B. G. 2003. Developing, Introducing dan Sustaining TQM.http://www.blackwellp ublishing.com) diakses November 2016.

Cannon, dkk. 2008. Pemasaran Dasar Buku 1 edisi 16. Jakarta : Salemba Empat.
2005. Manajemen Kualitas. PT.

Gramedia Pustaka Umum, Jakarta. 2009. Total Quality Management. Cetakan kelima. Gramedia Pustaka Utama, Jakarta. 2010. Principle of Marketing. Edisi 13. United States of America : Pearson.

Kotler, P. 2003. Marketing Management. Edisi 2. Jakarta : Salemba Empat. 2005. Manajemen Pemasaran di Indonesia . Buku 2. Jakarta : Salemba Empat.

2009. Manajemen Pemasaran. Jakarta : Erlangga.

Musran. 2010. Praktik Total Quality Management \& Pengaruhnya Terhadap Kinerja Karyawan. Jurnal Manajemen \& Kewirausahaan Vol 12. No $2185-194$.

Raymond Mc Leod. 2001. Sistem Informasi Manajemen. Jilid 1. Jakarta Prenhalindo.

Simamora. B. 2004. Riset Pemasaran. Jakarta : PT. Gramedia Pustaka Utama.

Siregar. 2013. Statistik Parametrik untuk Penelitian Kualitatif. Jakarta : Bumi Aksara.

Suwendra. 2014. Manajemen Kualitas Total. Graha Ilmu, Yogyakarta.

Tangkulung, 2015. Analisis Kepuasan Konsumen Terhadap Atribut Sayuran Organik Di Hypermart Manado. Skripsi Program Studi Agribisnis Fakultas Pertanian Universitas Sam Ratulangi.

Wishnu Perdana. 2013. Analisa Manajemen Kualitas dengan Metode TQM Berbasis Deming Prize di CV. EMWE Rona Jaya. Skripsi JurusanTeknik Industri Universitas Pembangunan Nasional Veteran, Jatim. 